\title{
Hyperglycaemia and its related risk factors in Ilam province, west of Iran- a population- based study
}

\author{
Khairollah Asadollahi ${ }^{1,2}$, Ali Delpisheh ${ }^{1,2}$, Parisa Asadollahi ${ }^{3}$ and Ghobad Abangah ${ }^{4 *}$
}

\begin{abstract}
Background: Impaired fasting glycaemia (IFG) has been defined as the fasting plasma glucose level between 6.1 $(110 \mathrm{mgl} / \mathrm{dl})$ and $6.9 \mathrm{mmol} / \mathrm{l}(125 \mathrm{mgl} / \mathrm{dl})$. Control of hyperglycaemia during acute illness among diabetic and nondiabetic patients has been associated with improved outcome. The aim of this study was to investigate the prevalence of and factors related to hyperglycaemia, IFG and diabetes in west of Iran.

Methods: This project was performed by a cross-sectional method in llam province including 2158 people $\geq$ 25 years old. From the list of all rural and urban health centers of each county, several were randomly selected. For each selected health centre, families numbered 1-20 completed questionnaire forms for all the members aging $\geq$ 25 years. FBS was measured for all the participants by standard method. All the demographic and laboratory results were analysed using SPSS 16. Descriptive and regression analysis were used for statistical analysis appropriately.

Results: A total of 2158 people were evaluated in this study, among which $72 \%$ were female with a mean age of $45.5 \pm 14$ years. $40 \%$ of participants were from urban regions and the mean height, weight, FBS and waist size of the participants were respectively as follows: $164 \pm 8.9 \mathrm{~cm}, 68.4 \pm 12.3 \mathrm{~kg}, 5.7 \pm 2.8 \mathrm{mmol} / \mathrm{l}(102.6 \pm 49.9 \mathrm{mg} / \mathrm{dl})$ and $82.3 \pm 14.3 \mathrm{~cm}$. The prevalence of IFG, diabetes and hyperglycaemia among participants were $7.8 \%, 11.8 \%$ and $19.6 \%$, respectively and participants from urban area showed a significantly higher prevalence of hyperglycaemia compared to rural regions $(P<0.0001)$.

Conclusion: The most effective factors associated with IFG and diabetes were family history of diabetes, age, hypertension, marital status, place of life and smoking, respectively. The prevalence of IFG, diabetes and hyperglycemia among the population living in Ilam province, west of Iran, were 7.8, 11.8 and $19.6 \%$ respectively which were directly increased with age.
\end{abstract}

Keywords: Hyperglycaemia, IFG, Diabetes, Ilam, Iran

\section{Introduction}

Plasma glucose is a continuous variable, with no definite "cut off" between normal and abnormal levels. High levels are usually associated with diabetes mellitus; however, relatively high levels may be detected in hospitalised patients in the absence of diabetes. Diagnostic criteria for diabetes are based on epidemiological evidences that identify levels, which predict the risk of future complications. Current diagnostic criteria were recently revised by the

\footnotetext{
* Correspondence: abangah_gh@yahoo.com

${ }^{4}$ Department of Gastroenterology, Faculty of Medicine, Ilam University of Medical Sciences, llam, Iran

Full list of author information is available at the end of the article
}

World Health Organisation (WHO), and include a plasma glucose level over $7.0 \mathrm{mmol} / \mathrm{l}(126 \mathrm{mgl} / \mathrm{dl})$ (Fasting) or over $11.1 \mathrm{mmol} / \mathrm{l}(200 \mathrm{mgl} / \mathrm{dl})$ (random). "Borderline" states of glucose intolerance are well recognised. Impaired glucose tolerance (IGT) [1] is diagnosed when the fasting plasma glucose is $<7.0 \mathrm{mmol} / \mathrm{l}(126 \mathrm{mgl} / \mathrm{dl})$, and 2-hour post-glucose load level is between $7.8(140 \mathrm{mgl} / \mathrm{dl})$ and $11.0 \mathrm{mmol} / \mathrm{l}(199 \mathrm{mgl} / \mathrm{dl})$. More recently, "impaired fasting glycaemia" (IFG) has been defined, where the fasting plasma glucose level is between $6.1(110 \mathrm{mgl} / \mathrm{dl})$ and $6.9 \mathrm{mmol} / \mathrm{l}(125 \mathrm{mgl} / \mathrm{dl})$ [1]. Both IGT and IFG probably represent states of glucose intolerance, which carry an

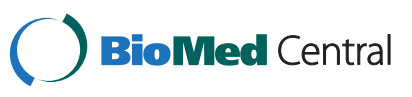

(C) 2015 Asadollahi et al. Open Access This article is distributed under the terms of the Creative Commons Attribution 4.0 International License (http://creativecommons.org/licenses/by/4.0/), which permits unrestricted use, distribution, and reproduction in any medium, provided you give appropriate credit to the original author(s) and the source, provide a link to the Creative Commons license, and indicate if changes were made. The Creative Commons Public Domain Dedication waiver (http://creativecommons.org/publicdomain/zero/1.0/) applies to the data made available in this article, unless otherwise stated. 
increased risk of the future development of type 2 diabetes, as well as of cardiovascular diseases [2].

Some, but by no means all, patients admitted with hyperglycaemia have diabetes, so either known or unknown diabetes may be a cause of admission hyperglycaemia. There are evidences that at least some of these patients may have previously had undiagnosed diabetes [3].

Hyperglycaemia is common in hospital in-patients. A study from the USA has shown that more than onethird (38\%) of all patients admitted to an urban general hospital had fasting blood glucose levels exceeding $7.0 \mathrm{mmol} / \mathrm{l}$, or 2 or more random blood glucose levels exceeding $11.1 \mathrm{mmol} / \mathrm{l}$ [4]. Another study investigated unrecognised diabetes among patients with coronary diseases and found that $46.6 \%$ of the patients had hyperglycaemia with no prior history of diabetes [5].

In the UK, about 1.4 million people are known to have diabetes (about $3 \%$ prevalence) and another million ( $2 \%$ of the population) have undiagnosed diabetes [6]. This prevalence is grossly similar to that in other countries. Studies from developed countries reported prevalence rates of 7-38 \% and mortality rates of 7.6-16\% associated with diabetes among general hospital admissions [4, 5, 7-12]. Globally, it was estimated that 382 million people suffered from diabetes with a prevalence rate of $8.3 \%$ in 2013. North America and the Caribbean are the regions with the higher prevalence rates of diabetes with a figure of $11 \%$, followed by the Middle East and North Africa with a prevalence rate of $9.2 \%$ and Western Pacific regions, with a prevalence rate of $8.6 \%$, closed to the global prevalence of diabetes. The number of people with diabetes is expected to rise to 592 million by 2035 . Most people with diabetes live in low and middle-income countries which will experience the greatest increase in cases of diabetes over the next 22 years [13].

Although diabetes mellitus and impaired glucose tolerance are worldwide health problems, hyperglycaemia alone can also create major health disorders. These disorders involve people either in developed or developing countries. Studies from developing countries [14-16] broadly show similar prevalence rates of diabetes to those found in developed nations; however, this is changing. For example a study from urban Colombian community showed that glucose intolerance was common and noted that it was likely to increase in the future urbanization and aging of the population [12]. This is a major concern in all the developing nations.

Treatment of diabetes involves medicines, diet, and exercise to control blood glucose and prevent symptoms and problems. Keeping an ideal body weight and an active lifestyle may prevent type 2 diabetes.
There is no way to prevent type 1 diabetes. The current population-based study was launched to investigate the prevalence of and factors related to hyperglycaemia, IFG and diabetes in Ilam province in the west of Iran.

\section{Methods \\ Study population}

This project was performed by a cross-sectional method in Ilam province, which included 2158 cases $\geq 25$ years old during 2011-2012. Ilam province is located at the west part of Iran with about $450 \mathrm{~km}$ line border with Iraq and, according to the census of 2012, with a population of 557,599 people. Rural and urban population of this province are 215,040 and 342,559 and their relevant number of people $\geq 25$ years old are 107,052 and 173,367 respectively.

\section{Sampling method}

The sample size needed for this project was estimated for 2158 people. The samples were selected by a multistage sampling method in which a population quota was firstly allocated to the rural and urban levels in Ilam province, considering the last national census in 2007. At the next step, the list of all rural and urban health centers of Ilam province was taken from Ilam University of Medical Sciences. There are 63 active health centers, including 31 rural and 32 urban, in Ilam province and according to the number of rural and urban health centers of each county and their related population, several health centers were selected randomly (simple randomization) as block levels in both urban and rural areas. Totally, 19 health centers including 9 from rural and 10 from urban areas were selected for this study that was about one third of all active health centers in the province. Then for each selected health centre, families' health dossier numbers 1-20 were chosen as household levels and investigators completed the questionnaire forms for all the selected family members aging $\geq 25$ years old. If any selected family was absent for completing the questionnaire or did not agree to participate in the study, the first house after the family dossier number of 20 was substituted. An adjustment for design effect and correlations among clusters was applied in this study. Participants were informed about the study objectives and were entered into the study if they accepted their participation orally.

\section{Data collection procedure}

All the participants who agreed to participate in the study were requested to attend in the nearest health centre for interview and laboratory test and those who could not attend or did not consent, were excluded. The information related to fasting blood sugar (FBS) taken 
and readiness to this test $(8-12 \mathrm{~h}$ fasting time before taking a blood sample) had already been prepared in a sheet and was submitted to each family at the day before the test. The importance of fasting before the test was explained, face to face, by questioners during the distribution of information sheets. If, for any reasons, the fasting was broken by the participants, the candidate person was excluded from the study.

Each participant was taken 2-3 cc vein blood sample after which the specimens were centrifuged and separated within 30-45 min following collection. The plasma of each sample was separated by centrifugation at $1542 \times \mathrm{g}(\sim 3000 \mathrm{rpm}) / 5 \mathrm{~min}$ (room temperature) with an interval time of plasma separation of $2 \mathrm{~h}$. The separated samples were then transferred to Ebnsina laboratory by cold packs or dry ice within 30 min to maximum $3 \mathrm{~h}$, depending on the distances between different counties and the laboratory centre. The FBS results equal to $7 \pm 0.17 \mathrm{mmol} / \mathrm{l}(126 \pm 3 \mathrm{mg} / \mathrm{dl})$ were retested for certainty and a FBS $\geq 7 \mathrm{mmol} / \mathrm{l}(126 \mathrm{mg} / \mathrm{dl})$ was considered as abnormal. Quality control was assayed each time the glucose method was performed by Westgard rules [17]. According to these rules controls were analyzed at the beginning of each run, periodically throughout and at the end of the run.

Demographic data were collected via interview and completing a validated questionnaire including age, sex, place of life, marital status, history of hypertension, family diabetes, daily exercise, smoking, weekly consumption of fruit, or animal oil. The data related to weight was then collected using a calibrated electronic digital scale, accurate to $100 \mathrm{~g}$ (Soehnle, Murrhardt, Germany) with subjects wearing only light underwear. Heights were measured to the nearest $0.1 \mathrm{~cm}$ using a Seca portable stadiometer while wearing no shoes and waist size was measured using a cloth tape measure by placing the tape measure midway between the hip bone and the bottom of lower ribs under the dresses.

Respondents were asked to report the frequency of consumption of a given serving of fruits or animal oil on a daily, weekly and monthly basis and data were then converted to weekly intake frequency and for daily exercise, participants were asked to report their daily or weekly physical activities (as hours) regardless of activities associated with their jobs and then converted to daily exercise.

\section{Study definitions}

Hyperglycemia was considered as an abnormally (greater than the upper limit of the normal range) high concentrations of glucose in the circulating blood. In our study, hyperglycemia comprised IFG (pre-diabetes), unknown and confirmed diabetes.
World Health Organization (WHO) criteria for impaired fasting glucose differs from the American Diabetes Association (ADA) or Diabetes UK criteria, because the normal range of glucose is defined differently by each. Fasting plasma glucose levels of $5.5 \mathrm{mmol} / \mathrm{l}(100 \mathrm{mg} / \mathrm{dl})$ and higher have been shown to significantly increase the complication rates; however, WHO opted to keep its normal upper limit under $6.1 \mathrm{mmol} / \mathrm{l}(110 \mathrm{mg} / \mathrm{dl})$ to avoid the diagnosis of too many people with impaired fasting glucose, whereas the ADA and Diabetes UK lowered the normal upper limit to a fasting plasma glucose under $100 \mathrm{mg} / \mathrm{dl}[18-20]$.

- The normal range by WHO criteria: fasting plasma glucose level lower than $6.1 \mathrm{mmol} / \mathrm{l}(110 \mathrm{mg} / \mathrm{dL})$

- The normal range by ADA criteria: fasting plasma glucose level lower than $5.6 \mathrm{mmol} / \mathrm{L}(100 \mathrm{mg} / \mathrm{dL})$

- The normal range by Diabetes UK criteria: fasting plasma glucose level from $3.9 \mathrm{mmol} / \mathrm{l}(70 \mathrm{mg} / \mathrm{dL})$ to $5.5 \mathrm{mmol} / \mathrm{L}(100 \mathrm{mg} / \mathrm{dL})$

\section{Data analysis}

All demographic and laboratory results were entered into a validated form and were then analysed using SPSS 16. Descriptive and regression analysis were used to estimate the prevalence of IFG, diabetes, hyperglycaemia and the effects /weights of each variable on these abnormalities. Descriptive tables were used to show the results and the mean value of different variables were compared using $t$-test or Chi squared accordingly.

\section{Ethical considerations}

This study was approved by ethic committee of Ilam University of Medical Sciences and was also financially supported by this university. Patients were entered into the study freely and did not pay for their FBS tests.

\section{Results}

A total of 2158 people were evaluated in this study, among which $72 \%$ were female with a mean age of $45.5 \pm$ 14 years. $40 \%$ of the participants were from rural regions and $60 \%$ from urban area. The mean height $(\mathrm{cm})$, weight $(\mathrm{kg})$, FBS $(\mathrm{mmol} / \mathrm{l}(\mathrm{mg} / \mathrm{dl}))$ and waist $(\mathrm{cm})$ of participants were as follows respectively: $164 \pm 8.9,68.4 \pm 12.3,5.7 \pm$ $2.8 \mathrm{mmol} / \mathrm{l}(102.6 \pm 49.9)$ and $82.3 \pm 14.3$. Most participants were married with a figure of $91.5 \%$. The prevalence of IFG, diabetes and hyperglycaemia among participants were $7.8 \%, 11.8 \%$ and $19.6 \%$, respectively and participants from urban area showed a significantly higher prevalence of hyperglycaemia than rural regions $(P<0.0001)$ (Table 1$)$. The prevalence rates of IFG, diabetes and hyperglycemia, all showed a positive relationship with age among the participants (Table 2). The comparisons between different levels of plasma 
Table 1 Frequency of different variables related to the participants of the diabetes study in llam Province

\begin{tabular}{|c|c|c|c|c|c|}
\hline \multicolumn{2}{|l|}{ Variable } & \multirow[t]{2}{*}{ Mean \pm SD } & \multirow{2}{*}{$\begin{array}{l}\text { Number } \\
(\%)\end{array}$} & \multicolumn{2}{|l|}{ Outcome } \\
\hline & & & & Yes & No \\
\hline \multicolumn{2}{|l|}{ Age (years) } & $45.5 \pm 14$ & - & - & - \\
\hline \multicolumn{2}{|c|}{ Height (Centimeter) } & $163.9 \pm 8.9$ & - & - & - \\
\hline \multicolumn{2}{|l|}{ Weight (kg) } & $68.4 \pm 12.3$ & - & - & - \\
\hline \multicolumn{2}{|c|}{ FBS mmol/l (mg/dl) } & $\begin{array}{c}5.7 \pm 2.8 \\
(102.6 \pm 49.9)\end{array}$ & - & - & - \\
\hline \multicolumn{2}{|c|}{ Waist size (Centimeter) } & $82.3 \pm 14.3$ & - & - & - \\
\hline \multirow[t]{2}{*}{ Gender } & Male & - & $602(28)$ & - & - \\
\hline & Female & - & $1553(72)$ & - & - \\
\hline \multirow[t]{2}{*}{ Place of life } & Urban & - & $1288(60)$ & - & - \\
\hline & Rural & - & $870(40)$ & - & - \\
\hline \multirow[t]{3}{*}{ Marital status } & Unmarried & - & $98(4.5)$ & - & - \\
\hline & married & - & $1974(91.5)$ & - & - \\
\hline & Widow & - & $60(3)$ & - & - \\
\hline \multicolumn{2}{|l|}{ History of HT } & - & - & $238(11 \%)$ & $1912(89 \%)$ \\
\hline \multicolumn{2}{|c|}{ Weekly serving of fruits } & - & - & $2082(97 \%)$ & $72(3 \%)$ \\
\hline \multicolumn{2}{|c|}{ History of family diabetes } & - & - & $192(9 \%)$ & $1901(88 \%)$ \\
\hline \multicolumn{2}{|l|}{ Daily exercise } & - & - & $1822(85 \%)$ & $322(15 \%)$ \\
\hline \multicolumn{2}{|l|}{ Smoking } & - & - & $103(5 \%)$ & $2052(95 \%)$ \\
\hline \multicolumn{2}{|c|}{ Weekly serving of animal oil } & - & - & $567(26 \%)$ & $1581(74 \%)$ \\
\hline
\end{tabular}

glucose and the participants' weight or waist size are available in Tables 3 and 4 .

Logistic regression was applied for 12 different variables investigated in this study and 6 variables of family history of diabetes, age, hypertension, marital status, place of life and smoking were identified more frequently in relation with disturbances of serum glucose levels. The method used for logistic regression analysis was "enter" or standard regression analysis and all the categorical predictor values were firstly defined and selected in the model. The logistic regression was applied for diabetes, IFG and hyperglycemia, as dependent variables, in three separated times (each time one dependent variable) with the same method. The results of univariate and multivariate analysis are summarized in Tables 5 and 6 . Four of the identified risk factors were evaluated by yes/no answers and the two variables of place of life and age were respectively evaluated based on whether the participants were living in a rural or urban area and if they were in an age group lower or higher than 50 years old. According to this analysis, the highest coefficient was related to positive history of diabetes, i.e., the possibility of having a serum glucose disturbance among those with a positive history of diabetes was more than those without. The availability rate of different variables to be included in the final analysis is shown by Table 7 .

\section{Discussion}

The prevalence of IFG, diabetes and hyperglycaemia among participants in the current study were 7.8, 11.8 and $19.6 \%$, respectively and participants from urban area showed a higher prevalence of hyperglycaemia than those from the rural regions. A study from Iran in 2009 reported a prevalence of $16.3 \%$ for diabetes in Yazd city and also reported that $14-23 \%$ of the Iranian population, with the age higher than 30 years old, are suffering from diabetes or IFG [21]. These figures are higher than what have been indicated in the current study. More studies from Iran by Janghorbani et al., Azizi et al., and Larijani et al., during 1997-2005 [22-25], reported prevalence rates of 4.6-10\% for diabetes which are more closed to what has been reported by the current study compared to the study in Yazd. The distribution of diabetes in Iran has been the subject of several surveys. Disease prevalence rates, for all forms of diabetes, have been variously reported as 7-17 \% in several adult urban populations. However, geographical prevalence is not uniform and the prevalence of type 2 diabetes mellitus has been reported at 3-5\% in rural communities. A screening program conducted at different locations of Iran revealed that nearly $50 \%$ of people with type 2 diabetes were unaware of their conditions [24]. Another national cross-sectional survey among 70,981 Iranian citizens, aged 25-64 years, found that 
Table 2 Frequency of participants according to the different plasma glucose levels and related prevalence

\begin{tabular}{|c|c|c|c|c|c|c|c|c|c|c|}
\hline \multirow[t]{2}{*}{ Variable } & & \multicolumn{5}{|c|}{$\begin{array}{l}\text { Number of patients according to plasma } \\
\text { glucose level }(\mathrm{mg} / \mathrm{dl})^{\mathrm{a}}\end{array}$} & \multirow[t]{2}{*}{$\begin{array}{l}\text { IFG } \\
{ }^{\mathrm{b}} \operatorname{Pr} \%(95 \% \mathrm{Cl})\end{array}$} & \multirow[t]{2}{*}{$\begin{array}{l}\text { Diabetes } \\
\text { Pr\% }(95 \% \mathrm{Cl})\end{array}$} & \multirow[t]{2}{*}{$\begin{array}{l}\text { Hyper-glycaemia } \\
\text { Pr\% }(95 \% \mathrm{Cl})\end{array}$} & \multirow[t]{2}{*}{$P$ value } \\
\hline & & $<70$ & $70-110$ & $111-125$ & $\geq 126$ & Total & & & & \\
\hline \multirow[t]{3}{*}{ Place of life } & Rural & 36 & 707 & 46 & 81 & 870 & $5.3(4.7-5.6)$ & $9.3(8.9-9.6)$ & $14.6(14.3-15.0)$ & 0.000 \\
\hline & Urban & 86 & 907 & 122 & 173 & 1288 & $9.5(9.1-10.0)$ & $13.4(12.8-13.7)$ & $22.9(22.0-23.6)$ & \\
\hline & Total & 122 & 1614 & 168 & 254 & 2158 & $8.2(7.8-8.6)$ & $11.8(11.3-12.2)$ & $20(19.2-20.9)$ & \\
\hline \multirow[t]{3}{*}{ Gender } & Male & 27 & 447 & 55 & 73 & 602 & $9.1(8.6-9.5)$ & $12.1(11.7-12.6)$ & $21.2(20.6-21.9)$ & 0.324 \\
\hline & Female & 95 & 1164 & 113 & 181 & 1553 & $7.3(6.7-7.8)$ & $11.7(11.1-12.3)$ & $19(18.5-19.7)$ & \\
\hline & Total & 122 & 1611 & 168 & 254 & 2155 & $7.8(7.2-8.3)$ & $11.8(11.4-12.1)$ & $19.6(19.1-20.2)$ & \\
\hline \multirow[t]{4}{*}{ Marital status } & Married & 113 & 1469 & 155 & 237 & 1974 & $7.9(7.3-8.5)$ & $12.3(11.7-12.9)$ & $20.2(19.4-21.0)$ & 0.033 \\
\hline & Unmarried & 7 & 81 & 6 & 4 & 98 & $6.1(5.5-6.7)$ & $4.1(3.5-4.7)$ & $10.2(9.8-10.7)$ & \\
\hline & Widow & 1 & 42 & 6 & 11 & 60 & $10(9.3-10.7)$ & $18.3(17.8-18.7)$ & $28.3(27.1-29.2)$ & \\
\hline & Total & 121 & 1592 & 167 & 252 & 2132 & $7.8(7.2-8.5)$ & $11.8(11.3-12.4)$ & $19.6(19.1-20.3)$ & \\
\hline \multirow[t]{3}{*}{ History of HT } & Yes & 5 & 157 & 25 & 51 & 238 & $10.5(10.2-10.9)$ & $21.4(21.0-21.8)$ & $31.9(30.8-32.5)$ & 0.001 \\
\hline & No & 116 & 1450 & 143 & 203 & 1912 & $7.5(7.1-7.9)$ & $10.6(10.3-11.0)$ & $18.1(17.7-18.5)$ & \\
\hline & Total & 121 & 1607 & 168 & 254 & 2150 & $7.8(7.4-8.2)$ & $11.8(11.4-12.3)$ & $19.6(19.1-20.1)$ & \\
\hline \multirow[t]{3}{*}{ Weekly using of fruit } & Yes & 114 & 1556 & 164 & 248 & 2082 & $7.9(7.4-8.3)$ & $11.9(11.4-12.6)$ & $19.8(19.1-20.6)$ & 0.000 \\
\hline & No & 8 & 54 & 4 & 6 & 72 & $5.6(5.1-5.9)$ & $8.3(7.8-8.8)$ & $13.9(13.0-14.7)$ & \\
\hline & Total & 122 & 1610 & 168 & 254 & 2154 & $7.8(7.4-8.3)$ & $11.8(11.1-12.7)$ & $19.6(18.9-20.3)$ & \\
\hline \multirow[t]{3}{*}{ History of family diabetes } & Yes & 14 & 107 & 15 & 56 & 192 & $7.8(7.5-8.1)$ & $29.2(28.3-29.6)$ & $37(36.5-37.6)$ & 0.000 \\
\hline & No & 108 & 1456 & 50 & 187 & 1901 & $2.6(2.3-3.0)$ & $9.8(9.4-10.2)$ & $12.4(11.9-12.8)$ & \\
\hline & Total & 122 & 1563 & 165 & 243 & 2093 & $7.9(7.5-8.3)$ & $11.6(11.1-12.0)$ & $19.5(18.9-20.1)$ & \\
\hline \multirow[t]{3}{*}{ Daily exercise } & Yes & 104 & 1382 & 134 & 202 & 1822 & $7.4(7.0-7.9)$ & $11.1(10.6-11.5)$ & $18.5(18.1-19.2)$ & 0.000 \\
\hline & No & 18 & 219 & 34 & 51 & 322 & $10.6(10.3-11.0)$ & $15.8(15.1-16.7)$ & $26.4(25.2-27.4)$ & \\
\hline & Total & 122 & 1601 & 168 & 253 & 2144 & $7.8(7.4-8.1)$ & $11.8(11.0-12.7)$ & $19.6(18.8-20.4)$ & \\
\hline \multirow[t]{3}{*}{ Smoking } & Yes & 4 & 73 & 12 & 14 & 103 & $11.7(11.3-12.2)$ & $13.6(13.1-14.0)$ & $25.3(24.6-26.1)$ & 0.000 \\
\hline & No & 118 & 1538 & 158 & 240 & 2052 & $7.7(7.2-8.1)$ & $11.7(11.2-12.1)$ & $19.4(18.6-20.2)$ & \\
\hline & Total & 122 & 1611 & 168 & 254 & 2155 & $7.8(7.5-8.3)$ & $11.8(11.1-12.4)$ & $19.6(18.7-20.5)$ & \\
\hline \multirow[t]{3}{*}{ Weekly using of animal oil } & Yes & 24 & 428 & 53 & 62 & 567 & $9.3(8.1-10.4)$ & $10.9(10.2-11.7)$ & $20.2(19.5-21.0)$ & 0.028 \\
\hline & No & 97 & 1177 & 115 & 192 & 1581 & $7.3(6.2-8.1)$ & $12.1(11.5-12.8)$ & $19.4(18.6-20.5)$ & \\
\hline & Total & 121 & 1605 & 168 & 254 & 2148 & $7.8(6.9-9.0)$ & $11.8(11.1-12.6)$ & $19.6(18.8-20.6)$ & \\
\hline \multirow[t]{4}{*}{ Age group (years) } & $25-40$ & 69 & 724 & 52 & 59 & 904 & $5.8(4.5-6.8)$ & $6.5(5.9-7.0)$ & $12.3(11.7-12.9)$ & 0.000 \\
\hline & $41-60$ & 43 & 672 & 77 & 141 & 933 & $8.3(7.1-9.5)$ & $15.1(14.4-15.7)$ & $23.4(22.1-24.9)$ & \\
\hline & $>60$ & 10 & 218 & 39 & 54 & 321 & $12.2(11.6-12.9)$ & $16.8(16.2-17.4)$ & $29(27.9-31.1)$ & \\
\hline & Total & 122 & 1614 & 168 & 254 & 2158 & $7.8(6.7-9.6)$ & $11.8(11.2-12.8)$ & $19.6(18.1-20.9)$ & \\
\hline
\end{tabular}

$H T$ hypertension, $F B S$ fasting blood glucose

${ }^{a} F B S:<3.9 \mathrm{mmol} / \mathrm{l}=<70 \mathrm{mg} / \mathrm{dl} ; \mathrm{FBS}: 3.9-6.1 \mathrm{mmol} / \mathrm{l}=70-110 \mathrm{mg} / \mathrm{dl} ; \mathrm{FBS}: 6.12-6.9 \mathrm{mmol} / \mathrm{l}=90-125 \mathrm{mg} / \mathrm{dl} ; \mathrm{FBS}: \geq 7 \mathrm{mmol} / \mathrm{l}(\geq 126 \mathrm{mg} / \mathrm{dl})$

bPr: prevalence

$7.7 \%$ of adults aged $25-64$ years ( 2 million adults) had diabetes, among whom one-half were undiagnosed. An additional $16.8 \%$ (4.4 million) of Iranian adults have impaired fasting glucose [26]. Therefore, this high rate of lack of awareness for serum glucose status may increase the chances of diabetes complications among Iranian population.

The prevalence of type 2 diabetes appears to be high among Iranian people over 40 years old with a figure of
$24 \%$ which increases by $0.4 \%$ each year after the age of 20 years. In a study, it was reported that the risk of type 2 diabetes was $1.7 \%$ greater in women compared to men [27]. It seems that the crude prevalence is not an appropriate indicator, due to differences in age pyramids, and an age-adjusted or age-specific prevalence should be used for this purpose.

Though our results showed a higher diabetes prevalence rate in Ilam province compared to the overall rate 
Table 3 Plasma glucose level of participants of the llam diabetes study, according to their weight groups

\begin{tabular}{|c|c|c|c|c|c|c|c|c|c|}
\hline \multirow[t]{2}{*}{ Variables } & & \multicolumn{8}{|l|}{ Weight group (kg) } \\
\hline & & Under 50 & $50-60$ & $61-70$ & $71-80$ & $81-90$ & $91-100$ & $\geq 100$ & Total \\
\hline \multirow{5}{*}{$\begin{array}{l}\text { Plasma glucose } \\
\text { level }\end{array}$} & $<3.9 \mathrm{mmol} / \mathrm{l}(<70 \mathrm{mg} / \mathrm{dl})(\mathrm{n})$ & 9 & 27 & 46 & 46 & 10 & 4 & 0 & 122 \\
\hline & 3.9-6.1 mmol/l (70-110 mg/dl) (n) & 95 & 331 & 552 & 552 & 148 & 41 & 22 & 1568 \\
\hline & $\begin{array}{l}6.1-6.9 \mathrm{mmol} / \mathrm{l}(111-125 \mathrm{mg} / \mathrm{dl}) \\
\text { (n) }\end{array}$ & 0 & 38 & 63 & 63 & 11 & 8 & 2 & 162 \\
\hline & $\geq 7 \mathrm{mmol} / \mathrm{l}(\geq 126 \mathrm{mg} / \mathrm{dl})$ & 15 & 56 & 79 & 79 & 27 & 8 & 1 & 246 \\
\hline & Total (n) & 119 & 452 & 740 & 740 & 196 & 61 & 25 & 2099 \\
\hline \multicolumn{2}{|c|}{ IFG prevalence\% (95\%CI) } & 0 & $8.4(8.1-8.8)$ & $8.5(8.1-8.9)$ & $8.5(8.1-8.9)$ & $5.6(5.4-5.8)$ & $13.1(12.7-13.5)$ & $8(7.5-8.4)$ & $7.7(7.2-8.1)$ \\
\hline \multicolumn{2}{|c|}{ Diabetes prevalence\% $(95 \% \mathrm{Cl})$} & $12.6(12.2-12.9)$ & $12.4(12.0-12.8)$ & $10.7(10.1-11.2)$ & $10.7(10.1-11.2)$ & $13.8(13.4-14.3)$ & $13.1(12.6-13.5)$ & $4(3.3-4.6)$ & $11.7(11.2-12.1)$ \\
\hline \multicolumn{2}{|c|}{ Hyperglycaemia prevalence\% (95\%Cl) } & $12.6(12.1-12.9)$ & $20.8(20.4-21.3)$ & $19.2(18.7-19.6)$ & $19.2(18.7-19.6)$ & $19.4(19.0-19.8)$ & $26.2(25.7-26.6)$ & $12(11.6-12.5)$ & 19.4 (18.9-19.7) \\
\hline
\end{tabular}


Table 4 Plasma glucose level of participants of the llam diabetes study, according to their waist size groups and gender

\begin{tabular}{|c|c|c|c|c|c|}
\hline \multirow{2}{*}{ Variable } & & \multicolumn{4}{|l|}{ Men waist size group $(\mathrm{cm})$} \\
\hline & & Under 94 & 94-102 & $>102$ & Total \\
\hline \multirow[t]{5}{*}{ Plasma glucose level } & $<3.9 \mathrm{mmol} / \mathrm{l}(<70 \mathrm{mg} / \mathrm{dl})(\mathrm{n})$ & 17 & 3 & 3 & 23 \\
\hline & 3.9-6.1 mmol/l (70-110 mg/dl) (n) & 224 & 62 & 37 & 323 \\
\hline & $6.1-6.9 \mathrm{mmol} / \mathrm{l}(111-125 \mathrm{mg} / \mathrm{dl})(\mathrm{n})$ & 33 & 2 & 1 & 36 \\
\hline & $\geq 7 \mathrm{mmol} / \mathrm{l}(\geq 126 \mathrm{mg} / \mathrm{dl})$ & 36 & 1 & 7 & 48 \\
\hline & Total (n) & 310 & 68 & 48 & 426 \\
\hline \multicolumn{2}{|c|}{ IFG Prevalence\% (95\%Cl) } & $10.65(10.3-11.0)$ & $2.9(2.3-3.4)$ & $2.1(1.8-2.5)$ & $8.5(8.1-8.8)$ \\
\hline \multicolumn{2}{|c|}{ Diabetes prevalence\% $(95 \% \mathrm{Cl})$} & $11.6(11.3-12.1)$ & $1.5(1.1-2.0)$ & $14.6(14.2-14.9)$ & $11.3(10.9-11.7)$ \\
\hline \multicolumn{2}{|c|}{ Hyperglycaemia prevalence\% (95\%Cl) } & $22.3(21.8-22.6)$ & $4.4(4.1-4.8)$ & $16.7(16.2-17.1)$ & $19.7(19.3-20.2)$ \\
\hline \multicolumn{6}{|c|}{ Women waist size group (cm) } \\
\hline \multirow[t]{6}{*}{ Plasma glucose level } & $<3.9 \mathrm{mmol} / \mathrm{l}(<70 \mathrm{mg} / \mathrm{dl})(\mathrm{n})$ & under 80 & $80-88$ & $>88$ & Total \\
\hline & & 49 & 17 & 17 & 83 \\
\hline & 3.9-6.1 mmol/l (70-110 mg/dl) (n) & 390 & 209 & 230 & 829 \\
\hline & $6.1-6.9 \mathrm{mmol} / \mathrm{l}(111-125 \mathrm{mg} / \mathrm{dl})(\mathrm{n})$ & 42 & 20 & 15 & 77 \\
\hline & $\geq 7 \mathrm{mmol} / \mathrm{l}(\geq 126 \mathrm{mg} / \mathrm{dl})$ & 57 & 37 & 28 & 122 \\
\hline & Total (n) & 538 & 283 & 290 & 1111 \\
\hline \multicolumn{2}{|c|}{ IFG prevalence\% $(95 \% \mathrm{Cl})$} & $7.8(7.1-8.2)$ & $7.1(6.7-7.5)$ & $5.2(4.9-5.6)$ & $6.9(6.4-7.3)$ \\
\hline \multicolumn{2}{|c|}{ Diabetes prevalence\% (95\%Cl) } & $10.6(10.2-10.9)$ & $13.1(12.9-13.5)$ & $9.7(9.4-10.1)$ & $11.0(10.7-11.2)$ \\
\hline \multicolumn{2}{|c|}{ Hyperglycaemia prevalence\% (95\%Cl) } & $18.4(18.0-18.7)$ & $20.1(19.7-20.6)$ & $14.8(14.3-15.5)$ & $17.9(17.5-18.3)$ \\
\hline
\end{tabular}

of the country, this figure is still lower than the prevalence rates reported from some other provinces such as Yaz (14.01 \%), Kerman (13.16 \%), Qazvin (13.09\%), Bushehr (12.62\%), and Isfahan (12.19\%). On the other hand, this prevalence rate is much higher than that in Kurdistan (3.35 \%), Lorestan (3.62 \%), Gilan (4.45\%), Zanjan (4.62\%) and some other provinces [27]. These discrepancies may be associated with verity of diabetes related risk factors in different geographical areas in Iran or differences in the methodology applied by different studies performed.

Studies from other parts of the world have reported either higher or lower prevalence of hyperglycaemia and IFG than the figure reported by the current study, which could be due to the effects of geographical conditions, nutritional habits, racial and genetically differences, customs, social behaviors and different life styles on diabetes and IFG. A study from the USA [4] in 2002, has reported a prevalence rate of $38 \%$ for hyperglycaemia among hospitalized patients but another study investigated unrecognised diabetes among patients with coronary diseases and found that $46.6 \%$ of patients had hyperglycaemia with no prior history of diabetes [5].

Amongst the top ten countries with the highest prevalence rates of diabetes, three are from the Middle East and North Africa Regions including Saudi Arabia, Kuwait, and Qatar with prevalence rates of 24, 23.1 and $22.9 \%$, respectively. Indeed, many of the countries in the Middle East and North Africa Regions have prevalence rates well above the global prevalence of $8.3 \%$, among which Egypt (15.6\%), Turkey (14.6\%), UAE (10\%) and Tunisia (9.2\%) have the highest prevalence rates, after the 3 above mentioned countries [28]. Iran with a total prevalence rate of $8.4 \%$ has approximately a similar rate to the global figure. As diabetes is a disease with multifactorial causes, associated with social, behavioral, occupational, life style and other factors, the discrepancies in its prevalence rates among different geographical regions, nations, societies and even different races in a city could be justifiable.

Community based studies, similar to the current study, have reported different prevalence of hyperglycaemia. For example, Cowie and others from the USA have reported a prevalence rate of $26 \%$ for IFG [9]; however, Meisinger and colleagues from Germany have reported an overall prevalence of $16 \%$ for either diabetes or abnormalities of glucose metabolism [10] and Sakikawas' study from Japan reported a figure of $12.9 \%$ [11].

The above mentioned studies were some samples of the developed countries; however, studies from developing countries have reported similar discrepancies for hyperglycaemia prevalence. A study from south of India by Mohan in 2003, reported a prevalence rate of $5.9 \%$ for IFG and $7.2 \%$ for diabetes [14] but another study by Shera from Pakistan in 2010, reported a prevalence of 
Table 5 Weighting given to different risk factors associated with diabetes, IFG and hyperglycaemia after univariate analysis

\begin{tabular}{|c|c|c|c|c|c|}
\hline \multirow{2}{*}{$\frac{\text { Type of disorder }}{\text { Diabetes }}$} & \multicolumn{2}{|l|}{ Variable } & \multirow{2}{*}{$\frac{\text { Weighting }}{56.647}$} & \multirow{2}{*}{$\frac{\operatorname{Exp}(B),(95 \% C l)}{3.265,2.87-3.66}$} & \multirow{2}{*}{$\begin{array}{r}P \text { value } \\
0.000\end{array}$} \\
\hline & Positive Family of diabetes & Yes & & & \\
\hline & & $\mathrm{No}^{\mathrm{b}}$ & & & \\
\hline & Age & $>50$ years & 35.126 & $2.224,1.71-2.89$ & 0.000 \\
\hline & & $\leq 50$ years $^{\mathrm{b}}$ & & & \\
\hline & History of hypertension & Yes & 22.676 & $1.436,1.14-1.83$ & 0.000 \\
\hline & & No ${ }^{b}$ & & & \\
\hline & Place of life & Urban & 8.406 & $1.511,1.14-1.99$ & 0.004 \\
\hline & & Rural $^{b}$ & & & \\
\hline & At least 30 min daily exercise & $Y_{e s}^{b}$ & 5.870 & $1.509,1.08-2.11$ & 0.015 \\
\hline & & No & & & \\
\hline & Married & Yes & 5.615 & $2.731,1.19-6.27$ & 0.018 \\
\hline & & $\mathrm{No}^{\mathrm{b}}$ & & & \\
\hline & Female Waist size & $>88 \mathrm{~cm}$ & 3.169 & $0.779,0.62-1.03$ & 0.075 \\
\hline & & $\leq 88^{\mathrm{b}} \mathrm{cm}$ & & & \\
\hline & Male Waist size & $>102 \mathrm{~cm}$ & 2.321 & $1.332,0.76-1.84$ & 0.091 \\
\hline & & $\leq 102^{\mathrm{b}} \mathrm{cm}$ & & & \\
\hline & Weekly using of fruit & Yes $^{\mathrm{b}}$ & 0.846 & $0.672,0.29-1.57$ & 0.358 \\
\hline & & No & & & \\
\hline & Weekly using of animal oil & Yes & 0.585 & $1.126,0.83-1.53$ & 0.444 \\
\hline & & $\mathrm{No}^{\mathrm{b}}$ & & & \\
\hline & Smoking & Yes & 0.338 & $0.842,0.47-1.5$ & 0.561 \\
\hline & & $\mathrm{No}^{\mathrm{b}}$ & & & \\
\hline & Sex & Male & 0.093 & $0.956,0.72-1.28$ & 0.761 \\
\hline & & Female $^{b}$ & & & \\
\hline & BMI & $>25$ & 0.063 & $1.034,0.79-1.34$ & 0.801 \\
\hline & & $\leq 25^{\mathrm{b}}$ & & & \\
\hline \multirow[t]{18}{*}{ IFG } & History of hypertension & Yes & 19.448 & $1.538,0.58-1.13$ & 0.000 \\
\hline & & $\mathrm{No}^{\mathrm{b}}$ & & & \\
\hline & Place of life & Urban & 18.685 & $1.672,1.32-2.11$ & 0.000 \\
\hline & & Rural $^{b}$ & & & \\
\hline & Male Waist size & $>102 \mathrm{~cm}$ & 12.331 & $1.812,1.23-2.14$ & 0.000 \\
\hline & & $\leq 102^{\mathrm{b}} \mathrm{cm}$ & & & \\
\hline & Female Waist size & $>88 \mathrm{~cm}$ & 9.881 & $1.691,1.43-1.97$ & 0.002 \\
\hline & & $\leq 88^{\mathrm{b}} \mathrm{cm}$ & & & \\
\hline & Married & Yes & 8.728 & $2.687,1.39-5.27$ & 0.003 \\
\hline & & $\mathrm{No}^{\mathrm{b}}$ & & & \\
\hline & Age & $>50$ years & 6.234 & $1.332,1.06-1.67$ & 0.013 \\
\hline & & $\leq 50$ years $^{\mathrm{b}}$ & & & \\
\hline & Smoking & Yes & 3.303 & $0.654,0.41-1.03$ & 0.069 \\
\hline & & $\mathrm{No}^{\mathrm{b}}$ & & & \\
\hline & Positive Family of diabetes & Yes & 2.921 & $1.099,0.74-1.63$ & 0.089 \\
\hline & & $\mathrm{No}^{\mathrm{b}}$ & & & \\
\hline & Weekly using of animal oil & Yes & 2.884 & $0.812,0.64-1.03$ & 0.638 \\
\hline & & No ${ }^{b}$ & & & \\
\hline
\end{tabular}


Table 5 Weighting given to different risk factors associated with diabetes, IFG and hyperglycaemia after univariate analysis (Continued)

\begin{tabular}{|c|c|c|c|c|c|}
\hline & \multirow[t]{2}{*}{ At least 30 min daily exercise } & Yes $^{\mathrm{b}}$ & \multirow[t]{2}{*}{2.679} & \multirow[t]{2}{*}{$1.275,0.95-1.71$} & \multirow[t]{2}{*}{0.102} \\
\hline & & No & & & \\
\hline & \multirow[t]{2}{*}{ Sex } & Male & \multirow[t]{2}{*}{2.135} & \multirow[t]{2}{*}{$0.838,0.66-1.06$} & \multirow[t]{2}{*}{0.144} \\
\hline & & Female $^{b}$ & & & \\
\hline & \multirow[t]{2}{*}{ Weekly using of fruit } & Yes $^{\mathrm{b}}$ & \multirow[t]{2}{*}{0.504} & \multirow[t]{2}{*}{$0.790,0.41-1.52$} & \multirow[t]{2}{*}{0.478} \\
\hline & & No & & & \\
\hline & \multirow[t]{2}{*}{ BMl } & $>25$ & \multirow[t]{2}{*}{0.286} & \multirow[t]{2}{*}{$1.061,0.85-1.32$} & \multirow[t]{2}{*}{0.593} \\
\hline & & $\leq 25^{b}$ & & & \\
\hline \multirow[t]{26}{*}{ Hyperglycaemia } & \multirow[t]{2}{*}{ Positive Family of diabetes } & Yes & \multirow[t]{2}{*}{25.743} & \multirow[t]{2}{*}{$2.459,1.93-2.86$} & \multirow[t]{2}{*}{0.000} \\
\hline & & $\mathrm{No}^{\mathrm{b}}$ & & & \\
\hline & \multirow[t]{2}{*}{ Age } & $>50$ years & \multirow[t]{2}{*}{39.798} & \multirow[t]{2}{*}{$1.846,1.53-2.23$} & \multirow[t]{2}{*}{0.000} \\
\hline & & $\leq 50$ years $^{b}$ & & & \\
\hline & \multirow[t]{2}{*}{ Place of life } & Urban & \multirow[t]{2}{*}{32.358} & \multirow[t]{2}{*}{$1.758,1.45-2.14$} & 0.000 \\
\hline & & Rural $^{\text {b }}$ & & & \\
\hline & History of hypertension & Yes & 19.448 & $1.538,1.31-1.78$ & 0.000 \\
\hline & & $\mathrm{No}^{\mathrm{b}}$ & & & \\
\hline & Married & $Y_{e s}^{b}$ & 16.999 & $2.071,1.8-5.24$ & 0.000 \\
\hline & & No & & & \\
\hline & Male Waist size & $>102 \mathrm{~cm}$ & 16.684 & $1.731,1.12-2.34$ & 0.000 \\
\hline & & $\leq 102^{\mathrm{b}} \mathrm{cm}$ & & & \\
\hline & Female Waist size & $>88 \mathrm{~cm}$ & 15.255 & $1.681,1.56-1.83$ & 0.001 \\
\hline & & $\leq 88^{\mathrm{b}} \mathrm{cm}$ & & & \\
\hline & At least 30 min daily exercise & Yes $^{\mathrm{b}}$ & 9.508 & $1.475,1.15-1.89$ & 0.002 \\
\hline & & No & & & \\
\hline & Smoking & Yes & 3.773 & $0.668,0.44-1.04$ & 0.052 \\
\hline & & $\mathrm{No}^{\mathrm{b}}$ & & & \\
\hline & Sex & Male & 2.098 & $0.861,0.71-1.65$ & 0.148 \\
\hline & & Female $^{b}$ & & & \\
\hline & Weekly using of fruit & Yes $^{b}$ & 1.550 & $0.704,0.41-1.22$ & 0.213 \\
\hline & & No & & & \\
\hline & BMl & $>25$ & 0.394 & $1.061,0.88-1.26$ & 0.530 \\
\hline & & $\leq 25^{\mathrm{b}}$ & & & \\
\hline & Weekly using of animal oil & Yes & 0.805 & $0.910,0.74-1.12$ & 0.370 \\
\hline & & $\mathrm{No}^{\mathrm{b}}$ & & & \\
\hline
\end{tabular}

Exp (B) ${ }^{a}$ : Indicates the odds of having the disease (e.g., diabetes) among those with the risk factor (e.g., Family diabetes) compared to those without that risk factor. ${ }^{b}$ reference group

total glucose intolerance of $16.7 \%$ for males and $19.4 \%$ for females [16].

The current study showed that the prevalence of hyperglycaemia and IFG among urban population was significantly higher compared to rural population. Though not significant, our study showed a higher prevalence of diabetes and IFG among males compared to females; however, other studies from Pakistan [16] and Colombia [12] reported a higher prevalence among females. A study by Sarah Wild and others in 2004 also reported a higher prevalence of diabetes among males compared to females [29].

According to the results of the current study, different cities of Ilam province have also shown different prevalence rates of diabetes and IFG from a minimum of $5.3 \%$ in Aivan county to a maximum of $14.8 \%$ in 
Table 6 Weighting given to different risk factors associated with diabetes, IFG and hyperglycaemia after multivariate analysis

\begin{tabular}{|c|c|c|c|c|c|}
\hline \multirow{2}{*}{$\begin{array}{l}\text { Type of disorder } \\
\text { Diabetes }\end{array}$} & \multicolumn{2}{|l|}{ Variable } & \multirow{2}{*}{$\frac{\text { Weighting }}{48.862}$} & \multirow{2}{*}{$\frac{\operatorname{Exp}(B)^{a},(95 \% C l)}{3.616,2.52-5.19}$} & \multirow{2}{*}{$\frac{P \text { value }}{0.000}$} \\
\hline & Positive Family of diabetes & Yes & & & \\
\hline & & $\mathrm{No}^{\mathrm{b}}$ & & & \\
\hline & Age & $>50$ years & 17.567 & $1.526,1.22-1.84$ & 0.000 \\
\hline & & $\leq 50$ years $^{b}$ & & & \\
\hline & History of hypertension & Yes & 7.244 & $1.697,1.15-2.53$ & 0.007 \\
\hline & & $\mathrm{No}^{\mathrm{b}}$ & & & \\
\hline & Place of life & Urban & 8.387 & $1.629,1.37-1.89$ & 0.004 \\
\hline & & Rural $^{\text {b }}$ & & & \\
\hline & Married & Yes & 3.791 & $1.558,1.24-2.31$ & 0.041 \\
\hline & & $\mathrm{No}^{\mathrm{b}}$ & & & \\
\hline & Smoking & Yes & 2.234 & $1.042,0.099-1.44$ & 0.048 \\
\hline & & $\mathrm{No}^{b}$ & & & \\
\hline & Female Waist size & $>88 \mathrm{~cm}$ & 2.134 & $1.283,0.92-1.83$ & 0.144 \\
\hline & & $\leq 88^{\mathrm{b}} \mathrm{cm}$ & & & \\
\hline & Male Waist size & $>102 \mathrm{~cm}$ & 2.107 & $1.461,0.87-2.44$ & 0.147 \\
\hline & & $\leq 102^{\mathrm{b}} \mathrm{cm}$ & & & \\
\hline & Weekly using of fruit & Yes $^{\mathrm{b}}$ & 0.555 & $1.395,0.58-3.35$ & 0.456 \\
\hline & & No & & & \\
\hline & Weekly using of animal oil & Yes & 0.542 & $0.886,0.64-1.22$ & 0.461 \\
\hline & & $\mathrm{No}^{\mathrm{b}}$ & & & \\
\hline & BMI & $>25$ & 0.324 & $0.9190 .69-1.23$ & 0.569 \\
\hline & & $\leq 25^{\mathrm{b}}$ & & & \\
\hline & At least 30 min daily exercise & Yes $^{\mathrm{b}}$ & 0.318 & $0.899,0.62-1.30$ & 0.573 \\
\hline & & No & & & \\
\hline & Sex & Male & 0.014 & $0.981,0.71-1.35$ & 0.905 \\
\hline & & Female $^{b}$ & & & \\
\hline \multirow[t]{18}{*}{ IFG } & Place of life & Urban & 14.057 & $1.616,1.48-1.79$ & 0.000 \\
\hline & & Rural $^{\text {b }}$ & & & \\
\hline & Married & Yes & 9.065 & $1.300,1.137-1.66$ & 0.003 \\
\hline & & $\mathrm{No}^{\mathrm{b}}$ & & & \\
\hline & Male Waist size & $>102 \mathrm{~cm}$ & 6.12 & $1.711,1.12-2.62$ & 0.013 \\
\hline & & $\leq 102^{\mathrm{b}} \mathrm{cm}$ & & & \\
\hline & Positive Family of diabetes & Yes & 4.228 & $1.907,0.61-1.35$ & 0.03 \\
\hline & & $\mathrm{No}^{\mathrm{b}}$ & & & \\
\hline & Weekly using of animal oil & Yes & 3.000 & $1.246,0.97-1.68$ & 0.083 \\
\hline & & $\mathrm{No}^{\mathrm{b}}$ & & & \\
\hline & Smoking & Yes & 2.795 & $1.211,0.74-1.97$ & 0.095 \\
\hline & & $\mathrm{No}^{\mathrm{b}}$ & & & \\
\hline & Female Waist size & $>88 \mathrm{~cm}$ & 2.542 & $1.256,0.96-1.65$ & 0.098 \\
\hline & & $\leq 88^{\mathrm{b}} \mathrm{cm}$ & & & \\
\hline & Age & $>50$ years & 2.272 & $0.824,0.64-1.06$ & 0.132 \\
\hline & & $\leq 50$ years $^{\mathrm{b}}$ & & & \\
\hline & BMI & $>25$ & 2.157 & $0.838,0.66-1.061$ & 0.142 \\
\hline & & $\leq 25^{\mathrm{b}}$ & & & \\
\hline
\end{tabular}


Table 6 Weighting given to different risk factors associated with diabetes, IFG and hyperglycaemia after multivariate analysis (Continued)

\begin{tabular}{|c|c|c|c|c|c|}
\hline & Sex & Male & 2.015 & $0.831,0.64-1.07$ & 0.156 \\
\hline & & Female $^{\mathrm{b}}$ & & & \\
\hline & Weekly using of fruit & $\mathrm{Yes}^{\mathrm{b}}$ & 0.184 & $1.157,0.65-2.25$ & 0.668 \\
\hline & & No & & & \\
\hline & History of hypertension & Yes & 0.718 & $1.171,0.81-1.75$ & 0.397 \\
\hline & & $\mathrm{No}^{\mathrm{b}}$ & & & \\
\hline & At least 30 min daily exercise & Yes $^{b}$ & 0.273 & $0.919,0.67-1.26$ & 0.601 \\
\hline & & No & & & \\
\hline Hyperglycaemia & Positive Family of diabetes & Yes & 27.876 & $2.154,1.63-2.95$ & 0.000 \\
\hline & & $\mathrm{No}^{\mathrm{b}}$ & & & \\
\hline & Age & $>50$ years & 22.211 & $1.626,1.504-1.78$ & 0.000 \\
\hline & & $\leq 50$ years $^{b}$ & & & \\
\hline & History of hypertension & Yes & 18.012 & $1.563,1.15-2.13$ & 0.005 \\
\hline & & $\mathrm{No}^{\mathrm{b}}$ & & & \\
\hline & Married & Yes & 12.240 & $1.343,1.19-1.63$ & 0.000 \\
\hline & & $\mathrm{No}^{\mathrm{b}}$ & & & \\
\hline & Place of life & Urban & 11.438 & $1.161,1.45-1.77$ & 0.000 \\
\hline & & Rural $^{\mathrm{b}}$ & & & \\
\hline & Male Waist size & $>102 \mathrm{~cm}$ & 9.721 & $1.76,1.23-2.51$ & 0.002 \\
\hline & & $\leq 102^{\mathrm{b}} \mathrm{cm}$ & & & \\
\hline & Female Waist size & $>88 \mathrm{~cm}$ & 6.057 & $1.341,1.06-1.75$ & 0.014 \\
\hline & & $\leq 88^{\mathrm{b}} \mathrm{cm}$ & & & \\
\hline & BMI & $>25$ & 3.084 & $0.832,0.68-1.02$ & 0.079 \\
\hline & & $\leq 25^{\mathrm{b}}$ & & & \\
\hline & Smoking & Yes & 1.372 & $1.149,0.74-1.79$ & 0.542 \\
\hline & & $\mathrm{No}^{\mathrm{b}}$ & & & \\
\hline & Weekly using of animal oil & Yes & 1.003 & $1.119,0.89-1.44$ & 0.317 \\
\hline & & $\mathrm{No}^{\mathrm{b}}$ & & & \\
\hline & Sex & Male & 1.553 & $0.867,0.69-1.15$ & 0.213 \\
\hline & & Female $^{b}$ & & & \\
\hline & Weekly using of fruit & Yes $^{\mathrm{b}}$ & 0.770 & $1.293,0.73-2.33$ & 0.380 \\
\hline & & No & & & \\
\hline & At least 30 min daily exercise & Yes $^{\mathrm{b}}$ & 0.715 & $0.888,0.68-1.17$ & 0.398 \\
\hline & & No & & & \\
\hline
\end{tabular}

Exp (B) ${ }^{a}$ : Indicates the odds of having the disease (e.g., diabetes) among those with the risk factor (e.g., Family diabetes) compared to those without that risk factor. ${ }^{b}$ : reference group

Mehran county for diabetes and between a minimum of $1.9 \%$ in Aivan county to a maximum of $11.8 \%$ in Chardavel county for IFG. These discrepancies may be related to the effects of geographical, customs, social behaviors and nutritional conditions on diabetes and IFG.

The prevalence of IFG, diabetes and hyperglycaemia among singles, married and widows were 6.1, 4.1, 10.2;
7.9, $12.3,20.2 \%$ and $10,18.3,28.3 \%$, respectively. This can indicate the effects of mean age on IFG and diabetes among married and widows compared to singles and the effect of age on IFG and diabetes is a recognized factor.

There was a significant difference between the prevalence of IFG, diabetes and hyperglycemia among those with hypertension compared to those without $(10.5 \%, 21.4 \%, 31.9 \%$ vs $7.5 \%, 10.6 \%, 18.1 \%$ 
Table 7 The availability rate of different variables. 'Classes' indicates the percentage of participants falling within each variable group. Some classes do not sum to $100 \%$ within each indicator because of missing data, so 'Available results' reports the percentage of patients for which data on that variable indicator was available

\begin{tabular}{|c|c|c|c|c|c|}
\hline \multirow[t]{2}{*}{ Variables } & & \multicolumn{3}{|c|}{ Number } & \multirow{2}{*}{$\begin{array}{l}\text { Non- } \\
\text { participation } \\
\text { rate\% }\end{array}$} \\
\hline & & Total & Classes\% & Available results $\%$ & \\
\hline \multicolumn{2}{|l|}{$\overline{\mathrm{FBS}}$} & 2158 & 100 & 100 & 0 \\
\hline \multicolumn{2}{|l|}{ Weight } & 2101 & 97.4 & 97.4 & 2.6 \\
\hline \multicolumn{2}{|l|}{ Height } & 2104 & 97.5 & 97.5 & 2.5 \\
\hline \multirow[t]{2}{*}{ Waist size } & male & 436 & 28.4 & 71.2 & 28.8 \\
\hline & female & 1100 & 71.6 & & \\
\hline \multirow[t]{2}{*}{ Gender } & Male & 652 & 28 & 100 & 0 \\
\hline & female & 1506 & 72 & & \\
\hline \multirow[t]{3}{*}{ BMI } & $<25$ & 998 & 48 & 96.3 & 3.7 \\
\hline & $25-30$ & 870 & 41.9 & & \\
\hline & $>30$ & 210 & 10.1 & & \\
\hline \multirow[t]{3}{*}{ Age group } & $25-40$ & 898 & 41.8 & 99.5 & 0.5 \\
\hline & $41-60$ & 929 & 43.3 & & \\
\hline & $>60$ & 321 & 14.9 & & \\
\hline \multirow[t]{2}{*}{ At least 30 min daily exercise } & Yes & 1822 & 85 & 97.4 & 2.6 \\
\hline & No & 322 & 15 & & \\
\hline \multirow[t]{2}{*}{ History of hypertension } & Yes & 238 & 11.1 & 97.6 & 2.4 \\
\hline & No & 1912 & 88.9 & & \\
\hline \multirow[t]{2}{*}{ Weekly using of animal oil } & Yes & 567 & 26.4 & 97.5 & 2.5 \\
\hline & No & 1581 & 73.6 & & \\
\hline \multirow[t]{2}{*}{ Family diabetes } & Yes & 192 & 9.2 & 97.0 & 3 \\
\hline & No & 1901 & 90.8 & & \\
\hline \multirow[t]{2}{*}{ Daily smoking } & Yes & 103 & 4.8 & 97.9 & 2.1 \\
\hline & No & 2052 & 95.2 & & \\
\hline \multirow[t]{2}{*}{ Weekly using of fruit } & Yes & 2082 & 96.7 & 97.8 & 2.2 \\
\hline & No & 72 & 3.3 & & \\
\hline \multirow[t]{2}{*}{ Place of life } & Rural & 870 & 40 & 100 & 0 \\
\hline & Urban & 1288 & 60 & & \\
\hline \multirow[t]{3}{*}{ Marital status } & Single & 98 & 4.6 & 98.8 & 1.2 \\
\hline & Married & 1974 & 92.6 & & \\
\hline & Widow/widower & 60 & 2.8 & & \\
\hline
\end{tabular}

respectively). This difference and any relationship between the history of hypertension and aggravation of IFG or diabetes should be approved by future studies.

The current study showed a significantly higher prevalence of hyperglycaemia among those with a history of family diabetes (37 \%) compared to those without (12.4\%). This difference has already been shown as a recognized factor by other references [29].

The prevalence of IFG, diabetes and hyperglycaemia was significantly higher among smokers, compared to non- smokers $(11.7 \%, 13.6 \%, 25.3 \%$ vs. $7.7 \%, 11.7 \%$,
$19.4 \%$, respectively). More studies need to approve the effects of this factor on diabetes and IFG.

There was a significantly positive relationship between age and diabetes or IFG. For example, the 9.8 and $24 \%$ prevalence of diabetes among participants with the age group of 21-30 years and those with the age group of 71-80 years were reported respectively [29].

Another factor related to diabetes in the current study was height. The prevalence rate of diabetes was $5.6 \%$ among the participants with a height of $150 \mathrm{~cm}$ or less and $18.1 \%$ among those with a height above $170 \mathrm{~cm}$. 
Considering a positive relationship between age and height, this process may be related to the effects of age on diabetes which has already been approved. Regardless of age, the pure effects of height on diabetes should be investigated by future studies.

There was a positive relationship between the prevalence of diabetes and waist size among men; for example, participants with a mean waist size of $70 \mathrm{~cm}$ had a diabetes prevalence of $11.6 \%$ compared to those with a mean waist above $102 \mathrm{~cm}$ who had a prevalence of $14.6 \%$. This could be due to accompany of fatness with higher waist size and the effects of fatness on diabetes has already been recognized [30].

This study was the first comprehensive population based survey for type 2 diabetes in Ilam province which could be used as a pilot study for any future interventional or preventive issues or academic researches in this province. A self-assessment predictive model for diabetes could be constructed upon the results of this study and we are now working on this model which could be applied by other provinces in the western part of Iran. This study also has some limitations such as lower proportion of recruited males and excess of participated women in the study, not a $100 \%$ availability rate for all the variables, and not performing GTT for diabetes confirmation when FBS was higher than $126 \mathrm{mg} / \mathrm{dl}$. Data collection and blood sampling were performed in the morning and in that particular time men were usually outside the home or not interested to participate in the study. However, there was a relatively large number of participants in this study and notwithstanding the excess number of women, there was still enough number of participated men for investigation and comparison of different variables.

\section{Conclusions}

The regression analysis revealed that the most effective factors associated with IFG and diabetes were family history of diabetes, age, hypertension, marital status, place of life and smoking, respectively. The prevalence of IFG, diabetes and hyperglycemia among population living in Ilam province, west of Iran, were 7.8, 11.8 and $19.6 \%$, respectively which were increased with age.

\section{Competing interests}

The authors declare that they have no competing interests.

\section{Authors' contributions}

AK carried out the design and coordinated the study, participated in most of study steps and prepared the manuscript. DA and AP assisted in the study design, data collection and manuscript preparation. AK and AG analyzed data and performed the final critical revision. All authors have read and approved the content of the manuscript.

\section{Acknowledgments}

We gratefully thank the School of Medicine, Ilam University of Medical Sciences, Vic Chancellor of Research and technology and Ebnsina laboratory for their valuable helps on this study. This work was financially supported by llam University of Medical Sciences.

\section{Author details}

${ }^{1}$ Department of Social Medicine, Faculty of Medicine, llam University of Medical Sciences, Ilam, Iran. ${ }^{2}$ Psychosocial Injuries Researches Center, Ilam University of Medical Sciences, Ilam, Iran. ${ }^{3}$ Microbiology Researches Center, Ilam University of Medical Sciences, Ilam, Iran. ${ }^{4}$ Department of

Gastroenterology, Faculty of Medicine, Ilam University of Medical Sciences, Ilam, Iran.

Received: 7 March 2015 Accepted: 5 September 2015

Published online: 23 October 2015

\section{References}

1. Engelgau MM. Diabetes diagnostic criteria and impaired glycemic states: evolving evidence Bas. Clin Diabetes. 2004;22(2):69-70.

2. David MN, Mayer BD, Robert JH, Robert RH, Richard P, Bernard Z. Impaired fasting glucose and impaired glucose tolerance. Diabetes Care. 2007;30(3):753-9.

3. Kathleen MD, Susan SB, Jean-Charles P. Stress hyperglycaemia. Lancet. 2009;373(9677):1798-807.

4. Umpierrez GE, Isaacs SD, Bazargan N, You X, Thaler LM, Kitabchi AE. Hyperglycemia: an independent marker of in-hospital mortality in patients with undiagnosed diabetes. J Clin Endocrinol Metab. 2002;87(3):978-82.

5. Taubert G, Winkelmann BR, Schleiffer T. Prevalence, predictors, and consequences of unrecognized diabetes mellitus in 3266 patients scheduled for coronary angiography. Am Heart J. 2003;145:285-91.

6. Diabetes UK. Recommendations for the provision of services in primary care for people with diabetes. 2005. http://www.guidelines.co.uk/endocrine_ duk_diabetes_jun12. Access date, Feb 2015.

7. Asadollahi K, Hastings IM, Beeching NJ, Gill GV. Laboratory risk factors for hospital mortality in acutely admitted patients. QJM. 2007;100(8):501-7.

8. Gray CS, Scott JF, French JM, Alberti KG, O'Connell JE. Prevalence and prediction of unrecognised diabetes mellitus and impaired glucose tolerance following acute stroke. Age Ageing. 2004;33(1):71-7.

9. Cowie CC, Rust KF, Byrd-Holt DD, Eberhardt MS, Flegal KM, Engelgau MM. Prevalence of diabetes and impaired fasting glucose in adults in the U.S. Population. National health and nutrition examination survey 1999-2002. Diabetes Care. 2006;29(6):1263-8.

10. Meisinger C, Strassburger K, Heier M, Thorand B, Baumeister SE, Giani G. Prevalence of undiagnosed diabetes and impaired glucose regulation in 35-59-year-old individuals in Southern Germany: the KORA F4 Study. Diabet Med. 2010;27(3):360-2.

11. Sekikawa A, Eguchi H, Tominaga M, Igarashi K, Takahashi A, Manaka H. Prevalence of diabetes mellitus and impaired glucose tolerance in a rural area of Japan. The Funagata diabetes study. J Daiabetes Complications. 2000;14(2):78-83.

12. Aschner P. Diabetes trends in Latin America. Diabetes Metab Res. 2002;18(3):S27-31.

13. Yuankai $\mathrm{S}$, Frank BH. The global implications of diabetes and cancer. The lancet 2014;383(9933):1947-8.

14. Mohan V, Shanthirani CS, Deepa R. Glucose intolerance (diabetes and IGT) in a selected South Indian population with special reference to family history, obesity and lifestyle factors-the Chennai Urban Population Study (CUPS 14). J Assoc Physicians India. 2003;51:771-7.

15. Erasmus RT, Blanco Blanco E, Okesina AB, Matsha T, Gqweta Z, Mesa JA. Prevalence of diabetes mellitus and impaired glucose tolerance in factory workers from Transkei, South Africa. S Afr Med J. 2001;91(2):157-60.

16. Shera AS, Basit A, Fawwad A, Hakeem R, Ahmedani MY, Hyderie MZ. Pakistan national diabetes survey: prevalence of glucose intolerance and associated factors in the Punjab Province of Pakistan. Prim Care Diabetes. 2010;4:79-83.

17. Westgard JO, Barry PL, Hunt MR, Groth T. A multi-rule Shewhart chart for quality control in clinical chemistry. Clin Chem. 1981;27:493-501.

18. World Health Organization. Definition, diagnosis and classification of diabetes mellitus and its complications: Report of a WHO Consultation. Part 1. Diagnosis and classification of diabetes mellitus. [Retrieved on 2007 May 29].

19. "Diagnosis and classification of diabetes mellitus". Diabetes Care. 2005;28(Suppl 1):S37-42. doi:10.2337/diacare.28.suppl_1.s37. 
20. Diabete.co.uk, Fasting Blood Sugar Levels: http://www.diabetes.co.uk/ diabetes_care/fasting-blood-sugar-levels.html access date May 2015.

21. Persianteb. 2012,<http://www.parsiteb.com/news.php?id=123\&action=view FullContent\&groupld=56>. Access date Feb 2015.

22. Janghorbani M, Amini M. Metabolic syndrome in type 2 diabetes mellitus in Isfahan, Iran: prevalence and risk factors. Metab Syndr Relat Disord. 2007:5(3):243-5.

23. Azizi F, Navai L. Study of the prevalence of diabetes and impaired glucose tolerance in rural areas of Tehran province. Hakim. 2001;2(4):112-8.

24. Larejani B, Zahedi F. Epidemiology of diabetes mellitus in Iran. Int J Tuberc Lung Dis. 2001;1(1):1-8

25. Azizi F, Rahmani M, Emami H, Mirmiran P, Hajipour R, Madjid M. Cardiovascular risk factors in an Iranian urban population: Tehran lipid and glucose study (phase 1). Soz Praventivmed. 2002;47(6):408-26.

26. Esteghamati A, Gouya MM, Abbasi M, Delavari A, Alikhani S, Alaedini F, et al. Prevalence of diabetes and impaired fasting glucose in the adult population of Iran. Diabetes Care. 2008;31(1):96-8.

27. Haghdoost AA, Rezazadeh KM, Sadghirad B, Baradaran HR. Prevalence of type 2 diabetes in the Islamic Republic of Iran: systematic review and metaanalysis. East Mediterr Health J. 2009;15(3):591-9.

28. Guariguata L, Whiting DR, Hambleton I, Beagley J, Linnenkamp U, Shaw JE. Global estimates of diabetes prevalence for 2013 and projections for 2035. Diabetes Res Clin Pract. 2014;103:137-49.

29. Wild S, Roglic G, Green A, Sicree R, King H. Global prevalence of diabetes: estimates for the year 2000 and projections for 2030. Diabetes Care. 2004;27(5):1047-53.

30. Australian facts. Diabetes: risk factors for diabetes and its complications. AlHW media release. 2008. p. 20-31.

\section{Submit your next manuscript to BioMed Central and take full advantage of:}

- Convenient online submission

- Thorough peer review

- No space constraints or color figure charges

- Immediate publication on acceptance

- Inclusion in PubMed, CAS, Scopus and Google Scholar

- Research which is freely available for redistribution 